\title{
Online learning readiness of the Science, Technology, and Engineering (STE) Program students of Sta. Cruz National High School during COVID-19 pandemic
}

Prontidão para aprendizagem online dos alunos do Programa de Ciência, Tecnologia e Engenharia (STE) da Sta. Cruz National High School durante a pandemia de COVID-19

Preparación para el aprendizaje en línea de los estudiantes del Programa de Ciencia, Tecnología e Ingeniería (STE) de Sta. Cruz National High School durante la pandemia de COVID-19

\author{
Ronald A. Diaz \\ Sta. Cruz National High School, Sta. Cruz, Davao del Sur, Philippines \\ rdhardcore@gmail.com, ronald.diaz@ deped.gov.ph \\ https://orcid.org/0000-0002-2982-9002
}

\begin{abstract}
The global health crisis created by COVID-19 has posed significant obstacles to the educational system, prompting a change from face-to-face classes to distance learning. In the middle of this global pandemic, different schools worlwide have used online learning as one of the distance learning modalities. This action research aimed to determine the online learning readiness of the Science, Technology, and Engineering (STE) Program students of Sta. Cruz National High School. A survey was used to determine the demographic profile and the online learning readiness level of these students in terms of expectations, self-direction, learning preferences, self-study habits, technology skills, hardware/software capabilities, and family support. This research utilized a quantitative descriptive research design. The results of this study shows that most of the STE students of this school have high level of online readiness in terms of expectations, self-direction, learning preferences, self-study habits, and technology skills. However, most of them only have an average level of online readiness in terms of hardware/software capabilities. Moreover, these students believed that their parents and family members are willing to support their needs that are essential for their active engagement in online learning. The findings of this research shall serve as basis for crafting policies, programs and projects to provide support in terms resources both physical and financial for the successful implementation of the online distance learning of students under the STE Program.
\end{abstract}

Keywords: Online Learning Readiness. Distance Learning.

\section{RESUMO}

A crise de saúde global criada pelo COVID-19 colocou obstáculos significativos ao sistema educacional, levando a uma mudança das aulas presenciais para o ensino à distância. No meio desta pandemia global, diferentes escolas em todo o mundo têm usado o ensino online como uma das modalidades de ensino à distância. Esta pesquisa-ação teve como objetivo determinar a prontidão para aprendizagem on-line dos alunos do Programa de Ciência, Tecnologia e Engenharia (STE) de Sta. Escola Secundária Nacional Cruz. Uma pesquisa foi usada para determinar o perfil demográfico e o nível de prontidão para aprendizagem online desses alunos em termos de expectativas, autodireção, preferências de aprendizagem, hábitos de auto-estudo, habilidades de tecnologia, recursos de hardware / software e suporte familiar. Esta pesquisa utilizou um desenho de pesquisa descritiva quantitativa. Os resultados deste estudo mostram que a maioria dos alunos STE desta escola tem alto nível de prontidão online em termos de expectativas, autodireção, preferências de aprendizagem, hábitos de auto-estudo e habilidades tecnológicas. No entanto, a maioria deles tem apenas um nível médio de prontidão online em termos de recursos de hardware / software. Além disso, esses alunos acreditavam que seus pais e familiares estão dispostos a atender às suas necessidades que são essenciais para seu envolvimento ativo na aprendizagem online. Os resultados desta pesquisa servirão de base para a elaboração de políticas, programas e projetos de apoio em termos de recursos físicos e financeiros para a implementação bemsucedida do ensino a distância online dos alunos do Programa STE.

Palavras-chave: Prontidão para Aprendizagem Online. Ensino à distância. 


\section{INTRODUCTION}

The recent global pandemic caused by the corona virus also known as the COVID-19 has brought tremendous challenges to all nations worldwide. This global health crisis also resulted to an unprecedented socio-economic crisis. One of the affected sectors of COVID-19 pandemic is the educational sector. Based from the United Nations (2020) report, the COVID-19 pandemic has created the largest disruption of education systems in history, affecting nearly 1.6 billion learners in more than 190 countries and all continents. Closures of schools and other learning spaces have impacted 94 per cent of the world's student population, up to 99 per cent in low and lower-middle income countries.

In the Philippines, more than 28 million learners are also affected by this health crisis (UNESCO, 2020). The difficulties in addressing the impact of the COVID-19 pandemic forced the Philippine government to make a decision to postpone the opening of public schools from June to October 5 to ensure the safety of students, teachers, and other school personnel (Palatino, 2020). Despite its decision to continue the formal education of Filipino learners in the country, schools and other community learning centers are still closed for physical conduct of classes or face-to-face.

As a response to education challenges brought about by COVID-19, the Department of Education has developed a Basic Education Learning Continuity Plan (BE-LCP). The BE-LCP constitutes a package of education interventions consisting of learning delivery strategy and operational direction that ensures the health, safety, and well-being of all learners, teachers and personnel of the Department. The key elements of the learning strategies that shall operationalize the BE-LCP are the streamlining of the $\mathrm{K}$ to 12 Curriculum into the Most Essential Learning Competencies (MELCs), and allowing of multiple learning delivery modalities such as distance learning and blended learning (DO 12, s. 2020).

One of the learning delivery modalities highlighted in the Basic Education Learning Continuity Plan is the distance learning which constitutes the modular distance learning, online distance learning, and TV/Radio-Based Instruction.

Based on the recent result from the automated LESF or Learner Enrolment and Survey Form, the modular distance learning obtained the highest result as the most preferred learning modality by the students and parents in the entire division of Davao del Sur. However, DO 12, s. 2020 also known as the Adoption of the Basic Education Learning Continuity Plan for School Year 2020-2021 in Light of the COVID-19 Public Health Emergency encourages schools to adopt flexible learning that is, it can adopt may be one or a combination of those different modalities, depending on the COVID-19 restrictions and the particular context of the learners in the school or locality.

Since 2011, Sta. Cruz National High School implements the Science, Technology, and Engineering (STE) Program (formerly ESEP) which envisions highly responsible, morally upright, globally competitive, and work-ready learners from schools offering relevant and innovative Science, Technology and Engineering education. The core subjects offered in the Secondary Education Curriculum (SEC) and under the K to 12 BEC were enhanced by additional subjects identified in the Revised Curriculum of the Engineering and Science Education Program (ESEP) of the S \& T-Oriented High Schools. The subject offerings, time allotment and unit credits stipulated in DepED Order No. 41, S. 2004 and DepED Order no. 31, S. 2012 were strictly implemented. In many schools offering the Program, add-on subjects in Science and Mathematics were offered on top of the requirements of the core curriculum and the special curricular program in science and technology. Add-on subjects such as Research, Biotechnology, Consumer Chemistry, Electronic, and Advanced Statistics contain lessons that are difficult to deliver to students using the modular distance learning.

The researcher believes that online learning will help STE teachers effectively deliver the lessons especially for add-on subjects which are considered advanced. Online distance learning shall also offer greater convenience for the teachers and learners, and offer flexibility in learning. It provides a direct access to a live teacher for inspiration, guidance and feedback. Teachers can cater 
to each student's proficiency level and learning goals by delivering different online resources (including videos, readings, and listenings) to individual students so they can work on them in their own time. Online learning can also provide more live opportunities for communicative practice with other students. Thus, this action research aims to determine the online learning readiness of the Science, Technology, and Engineering (STE) Program students of Sta. Cruz National High School. The result shall be used as basis for crafting an action plan or policies and guidelines in the implementation of online distance learning in the midst of the challenges brought by the COVID-19 health crisis.

\section{Objectives:}

This action research aimed to determine the online learning readiness of the Science, Technology, and Engineering (STE) Program students of Sta. Cruz National High School. Specifically, it aimed to achieve the following specific objectives:

1. Determine the demographic profile of STE student-respondents in terms of:
a. Age
b. Gender
c. Grade Level
d. Location or Barangay

2. Determine the percentage of STE students' available devices for online learning;

3. Determine the percentage of STE students' available Internet Service Provider (ISP) for online learning;

4. Determine the online learning readiness of the STE students in terms of:
a. expectations
b. self-direction
c. learning preferences
d. self-study habits
e. technology skills
f. hardware/software capabilities

5. Determine the students' perceived level of willingness of parents and/or family members to support the students' online learning in terms of financial assistance in purchasing prepaid/mobile load to access the internet.

\section{THEORETICAL FOUNDATION}

This research was anchored on Wave Theory by Toffler's (1980) which describe the changes over the course of humanity from agricultural age, industrial age, and into information age. The Information Age was the final or third wave which was triggered by the introduction of computers and electronic communications. Change is happening at a breakneck pace during this time, and keeping up is difficult. Toffler believes that educational systems are becoming co-opted by the current wave's prevailing needs. During the agricultural age, for example, extensive summer breaks were required so that young individuals could labor on farms. Punctuality, rule-following, and the ability to read and follow instructions were needed to produce good factory workers in the industrial age. Skills in science, technology, math, and computer languages were prioritized in the information age, therefore those subjects were highly promoted.

Toffler's Wave theory is also supported by Houle's (2012) Shift Age which describes the capacity to adapt rapidly to changing information and to handle effectively with a diversity of languages, cultures, and lifestyles will be required for an instantly connected global village and economy (Campbell, 2014).

This research is also anchored on Prensky's (2001) Digital Divide which he believes that that there is a "digital divide" between "digital natives" and "digital immigrants." Prensky's concept of "digital natives" and their computer-influenced learning styles emphasized the critical nature of 
pedagogy adaptation for this generation of students. This calls for an effective implementation of additional online courses and the incorporation of digital media into students' learning.

\section{METHODOLOGICAL PROCEDURES}

\subsection{Research Locale}

The study was conducted at Sta. Cruz National High School, Province of Davao del Sur, Region XI, Philippines. The school is located in Barangay Zone III, Poblacion, Sta. Cruz, Davao del Sur. The school has two campuses, the SCNHS Junior High School campus and the SCNHS Senior High School Campus. The Junior High School Campus is situated in a small lot, besides the Municipal Plaza while the Senior High School Campus is located along Rizal Street where the old public market was located.

Aside from the general curriculum, the school offers different special programs: the Science, Technology and Engineering (STE) Program, the Special Program in the Arts (SPA), Special Program in Foreign Language (SPFL), and the Special Education (SPED).

As a public school, Sta. Cruz National High School carries and embodies the vision, mission, goals, and the core values of the Department of Education.

\subsection{Respondents of the Study}

As of August 31, 2020, the total number of students under the Science, Technology, and Engineering (STE) Program of Sta. Cruz National High School is 204. Out of 204 population of STE students, a sample size of 162 respondents was surveyed which is beyond 148 expected sample size using the slovin's formula: $\mathrm{n}=\mathrm{N} \div\left(1+\mathrm{Ne}^{2}\right)$.

\subsection{Research Design}

To determine the online learning readiness of STE Students of Sta. Cruz National High School this study utilized a quantitative descriptive research design.

\subsection{Research Instrument}

A questionnaire was used to assess the online learning readiness of STE Students of Sta. Cruz National High School. A multi-dimensional standard scale shall be adopted from Williams (nd) of Penn State University which consists of 24 questions which measures the level of online learning readiness of students in terms expectations, self-direction, learning preferences, self-study habits, technology skills, and hardware/software capabilities.

The questionnaire was transcribed and uploaded through Google Form in order for the student-respondents to virtually respond to the questions.

\subsection{Data Gathering Procedure}

The following procedure in the data gathering shall be performed.

1. The researcher asked a permission from the school principal of Sta. Cruz National High School and from the Schools Division Superintendent to conduct the study.

2. The questionnaires were sent randomly to the STE students of the school last September, 2020.

3. The data was tabulated in MS excel and was analyzed using the SPSS software.

\subsection{Data Analysis}

The data was descriptively analyzed using mean, percentage and standard deviation. 


\section{RESULTS AND DISCUSSION}

\subsection{Results}

\section{Demographics}

The distribution of the respondents of the study as to age is shown in Table 1. Result shows that most of the students' age is 13 .

Table 1. Distribution of respondents in terms of age

\begin{tabular}{ccc}
\hline Age & N & Percent \\
\hline 12 & 10 & 6.2 \\
13 & 58 & 35.8 \\
14 & 51 & 31.5 \\
15 & 37 & 22.8 \\
16 & 6 & 3.7 \\
\hline Total & 162 & 100 \\
\hline
\end{tabular}

The distribution of the respondents of the study as to sex is shown in Table 2. Result shows that most of the respondents were female.

Table 2. Distribution of respondents in terms of sex

\begin{tabular}{lcc}
\multicolumn{1}{c}{ Sex } & N & Percent \\
\hline Female & 114 & 70.4 \\
Male & 48 & 29.6 \\
\hline \multicolumn{1}{c}{ Total } & 162 & 100 \\
\hline
\end{tabular}

Presented in Table 3 is the distribution of student-respondents in terms of grade level. The table shows that most of the respondents are Grade 9 students in the STE Program with a percentage of $31.5 \%$.

Table 3. Distribution of students in terms of grade level

\begin{tabular}{ccc}
\hline Grade Level & N & Percent \\
\hline 7 & 20 & 12.3 \\
8 & 43 & 26.5 \\
9 & 51 & 31.5 \\
10 & 48 & 29.6 \\
\hline Total & 162 & 100 \\
\hline
\end{tabular}

The data presented in Table 4 shows the distribution of respondents in terms of their location or Barangay in Sta. Cruz, Davao del Sur, Philippines. Results show that most of the respondents of this study are situated in Barangay Zone III.

\section{N Percent}




\begin{tabular}{|c|c|c|c|c|}
\hline \multirow[t]{2}{*}{ Table 4.} & Astorga & 1 & .6 & \multirow{11}{*}{$\begin{array}{c}\text { Distribution of } \\
\text { Respondents in } \\
\text { Location / }\end{array}$} \\
\hline & Coronon & 27 & 16.7 & \\
\hline terms of & Saliducon & 1 & .6 & \\
\hline Barangay & Sinuron & 4 & 2.5 & \\
\hline & Tagabuli & 4 & 2.5 & \\
\hline & Tuban & 12 & 7.4 & \\
\hline & Zone I & 19 & 11.7 & \\
\hline & Zone II & 18 & 11.1 & \\
\hline & Zone III & 53 & 32.7 & \\
\hline & Zone IV & 23 & 14.2 & \\
\hline & Total & 162 & 100.0 & \\
\hline
\end{tabular}

Table 5 shows the percentage of the STE students' available devices for online learning. Results show that most of the STE students have smartphones and only few have tablets.

Table 5. Percentage of STE students' available devices for online learning

\begin{tabular}{lrr}
\hline Available Devices & N & Percent \\
\hline None & 20 & 12.3 \\
Desktop Computer & 13 & 8.0 \\
Laptop & 39 & 24.1 \\
Tablet & 11 & 6.8 \\
Smartphone & 79 & 48.8 \\
\hline Total & 162 & 100.0 \\
\hline
\end{tabular}

The data presented in Table 6 shows the percentage of the available internet service provider (ISP) present in every STE student's barangay. It shows that of STE students (48.8\%) are using Smart/TNT network in accessing the internet needed for online learning .

Table 6. Percentage of STE students' available Internet Service Provider (ISP) for online learning

\begin{tabular}{lrr} 
Internet Service Provider & \multicolumn{1}{c}{ N } & Percent \\
\hline No Available ISP & 9 & 5.6 \\
PLDT & 27 & 16.7 \\
Sun & 4 & 2.5 \\
Smart/TNT & 79 & 48.8 \\
Globe/TM & 43 & 26.5 \\
\hline Total & 162 & 100.0 \\
\hline
\end{tabular}

\section{Online Learning Readiness of STE Students}

Presented in Table 7 is the online readiness result of STE students in terms of expectations. Results show that 85.70 percent of the respondents understood that learning is their responsibility. They believed that online class is not easier than a traditional class. They are also willing to send emails to or have online discussions with people they may never meet in person. 
Table 7. Online Learning Readiness in terms of Expectations

\begin{tabular}{lrrcc}
\hline \multicolumn{1}{c}{ Responses } & N & Percent & Mean & SD \\
\hline Agree & 139 & 85.80 & 2.69 & 0.27 \\
Somewhat Agree & 23 & 14.20 & & \\
Disagree & 0 & 0.00 & & \\
\hline Total & 162 & 100 & & \\
\hline
\end{tabular}

When it comes to self-direction, the results shown in Table 8 shows that 74.69 percent of the respondents are ready for online learning. They agree that they are good at setting goals and deadlines for themselves. They are self-motivated and can work on projects through completion. They can keep their selves on track and meet deadlines.

Table 8. Online Learning Readiness in terms Self-Direction

\begin{tabular}{lrrcc}
\hline \multicolumn{1}{c}{ Responses } & N & Percent & Mean & SD \\
\hline Agree & 121 & 74.69 & 2.65 & 0.41 \\
Somewhat Agree & 40 & 24.69 & & \\
Disagree & 1 & 0.62 & & \\
\hline Total & 162 & 100 & & \\
\hline
\end{tabular}

Table 9 shows that 83.95 percent of the students are ready for online learning in terms of learning preferences. These respondents agree that they enjoy reading and can retain information studying in this manner. They also agree on the statements that they can learn from auditory content, such as lectures, recordings, or podcasts. They also agree that they are comfortable communicating through writing. They can also learn on their own but can benefit from working in a group as well.

Table 9. Online Learning Readiness in terms Learning Preferences

\begin{tabular}{lrrcc}
\hline \multicolumn{1}{c}{ Responses } & N & Percent & Mean & SD \\
\hline Agree & 136 & 83.95 & 2.70 & 0.30 \\
Somewhat Agree & 26 & 16.05 & & \\
Disagree & 0 & 0.00 & & \\
\hline Total & 162 & 100 & & \\
\hline
\end{tabular}

Presented in Table 10 is the online readiness result of STE students in terms of study habits. Out of 162 student-respondents, 58.02 percent of them agree on the statements saying they have a dedicated study space where they can read and work on assignments without distraction. They can also spend more than 8.5 hours a week. They can also organize their coursework in a computer folder for easy reference and dedicate a specific time of day or night to work on their studies.

Table 10. Online Learning Readiness in terms Study Habits

\begin{tabular}{lrrcc}
\hline \multicolumn{1}{c}{ Responses } & N & Percent & Mean & SD \\
\hline Agree & 94 & 58.02 & 2.55 & 0.33 \\
Somewhat Agree & 67 & 41.36 & & \\
Disagree & 1 & 0.62 & & \\
\hline Total & 162 & 100 & & \\
\hline
\end{tabular}


When it comes to technology skills, the results shown in Table 11 shows that 47.53 percent of the respondents are ready for online learning. This results indicate that most of the agree to the statement saying that they are fairly good at using a computer and sending email. They are also comfortable using web browsers and navigating the Internet. They also know how to download files and add attachments and can use word processing software.

Table 11. Online Learning Readiness in terms Technology Skills

\begin{tabular}{lrrcc}
\hline \multicolumn{1}{c}{ Responses } & N & Percent & Mean & SD \\
\hline Agree & 77 & 47.53 & 2.41 & 0.51 \\
Somewhat Agree & 76 & 46.91 & & \\
Disagree & 9 & 5.56 & & \\
\hline Total & 162 & 100 & & \\
\hline
\end{tabular}

Table 12 shows that most of the students at a percentage of 53.09 somewhat agree that they are ready for online learning in terms of hardware and/or software requirements. Not all of them have a computer that runs reliably on Windows or Mac OS. Not all of them have internet access with a fairly fast, reliable connection. Not all of them have a printer. Only few of them have headphones or speakers and a microphone if a class has a videoconference.

Table 12. Online Learning Readiness in terms Hardware / Software Requirements

\begin{tabular}{lrrcc}
\hline \multicolumn{1}{c}{ Responses } & N & Percent & Mean & SD \\
\hline Agree & 39 & 24.07 & 2.01 & 0.61 \\
Somewhat Agree & 86 & 53.09 & & \\
Disagree & 37 & 22.84 & & \\
\hline Total & 162 & 100 & & \\
\hline
\end{tabular}

\section{Overall Online Learning Readiness}

Table 13 shows the overall online learning readiness of STE students according to grade level. The Grade 8 students have the highest overall online learning readiness level $(\mathrm{M}=2.60$, $\mathrm{SD}=0.2517)$ compared to other grade level. The Grade 10 students indicates the lowest level of online learning readiness level. The results further shows that on a scale of 3 , the mean overall online learning readiness level of the STE students of Sta. Cruz National High School is 2.50 with a standard deviation of 0.2779 .

Table 13. Overall Online Learning Readiness of STE Students according to Grade Level

\begin{tabular}{ccccc}
\hline Grade Level & N & Percent & Mean & SD \\
\hline 7 & 20 & 12.35 & 2.4720 & 0.1472 \\
8 & 43 & 26.54 & 2.6035 & 0.2517 \\
9 & 51 & 31.48 & 2.5294 & 0.3171 \\
10 & 48 & 29.63 & 2.3885 & 0.2618 \\
\hline Total & 162 & 100.00 & 2.5002 & 0.2779 \\
\hline
\end{tabular}




\section{Parental and/or Family Support}

In terms of parental and/or family support, 69.8 percent of the student-respondents agree that their parents and/or family members are willing to support their online learning endeavors in terms of financial assistance in purchasing prepaid/mobile load to access the internet.

Table 12. Students' perceived level of support of parents and/or family members

\begin{tabular}{lrrrl}
\hline Responses & \multicolumn{1}{c}{ N } & Percent & Mean & SD \\
\hline Agree & 113 & 69.8 & 2.6 & 0.60 \\
Somewhat Agree & 39 & 24.1 & & \\
Disagree & 10 & 6.2 & & \\
\hline Total & 162 & 100.0 & & \\
\hline
\end{tabular}

\subsection{Discussion}

Based on the results of the study, it appears that the Science, Technology, and Engineering (STE) Program students of Sta. Cruz National High School for SY 2020-2021 have a good awareness of what is required of them as students in an online class. Online learning can be a gratifying approach to enhance their education, but it is not as simple as a regular class, and they must be able to learn independently as well as collaborate with their peers.

The results also tell us that these students are self-directed, organized, and ready to face the obstacles of working independently as an online learner.

The findings demonstrate that they are adaptable in their learning preferences, confident in their abilities to solve challenges, and at ease working as individual or in groups. These characteristics will assist them in adjusting to the online learning environment.

The responses of these STE students in the survey show that they are focused, capable of prioritizing their work to meet deadlines, willing to accept help from others, and eager to devote the time required to successfully reach their learning objectives. Each of these study skills will assist them in meeting the learning objectives for their online course.

When it comes to technological skills, the results show that they are confident computer users with the required skills to handle their computing environment, either on their own or with the assistance of appropriate sources.

In terms of computer equipment capabilities, the results suggest that they may require certain hardware updates or additional software to ensure the greatest possible experience while participating in online learning. To offer the greatest possible online learning experience, their computers may require certain upgrades or additional software to be installed. they should have a modern, up-to-date operating system, a current browser, a reasonably fast Internet connection, virus protection, and potentially headphones with a microphone.

The results of the study further tell us that the parents and family members of these STE students of Sta. Cruz National High School are wholeheartedly support their learners endeavors in engaging online learning by providing financial assistance in terms of purchasing mobile loads to access online learning sites or platforms and other undertakings to actively participate in the virtual classroom. This support is very essential for these students to cope up the different challenges that they may face in distance learning education most especially in an online learning modality.

\section{CONCLUSION}

This study aimed to determine the online learning readiness of the Science, Technology, and Engineering (STE) Program students of Sta. Cruz National High School. The findings of this study 
shows that most of the STE students of this school have a high level of online readiness in terms of expectations, self-direction, learning preferences, self-study habits, and technology skills. However, most of them only have an average level of online readiness in terms of hardware/software capabilities. Moreover, these students believed that their parents and family members are willing to support their needs in terms of financial support and other things that are essential for their active engagement in online learning.

\section{Plan of Actions}

Based on the findings of this study, the researcher and the members of the STE Program Department of Sta. Cruz National High School have decided to take some steps to address and take actions on the least area of the online readiness of the STE students, that is, the hardware/software capabilities. In coordination with the school administration, the Science, Technology and Engineering (STE) Program Department of the school shall source-out resources from different stakeholders most specifically gadgets like smartphones or tablets which can be used for online learning. These gadgets shall be distributed to those less-privilege and deserving STE students who are having financial difficulties to provide equipment and other materials needed in their online learning.

The STE Program Department shall conduct different training-workshops or capability building to teachers handling the different STE Program subjects. In this way, these teachers will be able to enhance their knowledge and skills of the different online distance learning platforms or tools in which they can use to facilitate effectively the online learning activities of their students. They would also learn on the different strategies and on what platforms or tools to adopt which are suited on their students' learning conditions or needs.

A participatory approach in crafting guidelines and policies to provide the needed support in terms resources both physical and financial for the successful implementation of the online distance learning of students under the STE Program shall be conducted among the members of the school administration, the STE Program teachers, the parents, and other stakeholders of Sta. Cruz National High School.

\section{REFERENCES}

Campbell, N. (2014). Book Review: Entering the Shift Age: The End of the Information Age and the New Era of Transformation. Journal of Macromarketing, 34(1), 95-97. https://doi.org/10.1177/0276146713507957

Palatino, M. (2020). Are Schools in the Philippines Ready to Open in a Pandemic? The Diplomat. Retrieved from: https://thediplomat.com/2020/08/are-schools-in-the-philippines-ready-to-open-in-a-pandemic/

Prensky, M. (2001). Digital Natives, Digital Immigrants. Retrieved from: https://www.marcprensky.com/writing/Prensky\%20-\%20Digital\%20Natives,\%20Digital\%20Immigrants\%20$\% 20$ Part1.pdf

Rodriquez, F. (2015). Learning How to Learn: Reflecting on the Work of Alvin Toffler. Extended Campus: The University of Oklahoma. Retrieved from: https://pacs.ou.edu/blog/learning-how-to-learn-reflecting-on-thework-of-alvin-toffler/

UNESCO. (2020). COVID-19 Educational Disruption and Response. Retrieved from https://en.unesco.org/covid19/educationresponse

United Nations (2020). Policy Brief: Education during COVID-19 and beyond. Retrieved from: https://www.un.org/development/desa/dspd/wp-content/uploads/sites/22/2020/08/sg_policy_brief_covid19_and_education_august_2020.pdf

Williams, M. (nd). Online Readiness Questionnaire. Penn State University. Retrieved form: https://www.ncc.edu/programsandcourses/distance_ed_online/self_eval/assessment.html 